\title{
Faktor Adversity Quotient dalam Kemampuan Pemecahan Masalah Pembuktian Matematis Topik Teori Grup
}

\author{
Fauziah Hakim \\ Program Studi Pendidikan Matematika, FKIP, Universitas Sulawesi Barat \\ e-mail:fauziahhakim@unsulbar.ac.id
}

\begin{abstract}
Abstrak
Salah satu masalah matematika yang sering dihadapi mahasiswa dalam proses pembelajaran adalah masalah pembuktian matematis. Pembuktian matematis hadir di banyak mata kuliah, salah satunya pada topik Teori Grup yang ada pada mata kuliah Struktur Aljabar. Pemecahan masalah pembuktian matematis memerlukan daya juang dalam penyelesaiannya mengingat prosesnya yang memerlukan pemikiran tingkat tinggi. Salah satu faktor yang diduga terkait adalah adversity quotient. Penelitian ini bertujuan melihat pengaruh adversity quotient terhadap kemampuan pemecahan masalah pembuktian matematis topik Teori Grup. Penelitian ini menggunakan pendekatan kuantitatif dengan metode korelasional. Populasi pada penelitian ini adalah seluruh mahasiswa Program Studi Pendidikan Matematika Universitas Sulawesi Barat yang sedang memprogramkan mata kuliah Struktur Aljabar pada tahun akademik 2019/2020, sedangkan sampelnya adalah 30 orang mahasiswa yang dipilih secara acak dari populasi tersebut. Data yang diperoleh dari Adversity Response Profile (ARP) Quick Take $^{\text {TM }}$ dan Tes Kemampuan Pemecahan Masalah Pembuktian Matematis Topik Teori Grup dianalisis dengan teknik regresi linear sederhana berbantuan perangkat lunak dengan uji prasyarat berupa uji normalitas dan uji linearitas. Pengujian yang digunakan adalah uji dua pihak dengan taraf signifikansi $5 \%$. Berdasarkan analisis data diperoleh kesimpulan bahwa adversity quotient berpengaruh signifikan terhadap kemampuan pemecahan masalah pembuktian matematis topik Teori Grup. Dari hasil analisis lanjutan juga diperoleh bahwa pengaruh tersebut merupakan pengaruh positif namun berada pada kategori lemah.
\end{abstract}

Kata Kunci: Adversity quotient, pemecahan masalah, pembuktian matematis

\section{PENDAHULUAN}

Pembuktian matematis merupakan masalah matematika yang sering dihadapi mahasiswa dalam proses perkuliahan. Beberapa topik mata kuliah erat kaitannya dengan masalah pembuktian, salah satunya adalah Teori Grup. Teori Grup merupakan materi dasar dari mata kuliah Struktur Aljabar yang sarat dengan definisi dan teorema. Menurut Suradi (dalam Soenarto, 2011), Struktur Aljabar merupakan mata kuliah yang diberikan kepada mahasiswa dengan tujuan mahasiswa memahami struktur-struktur dalam aljabar, mampu menerapkannya untuk memecahkan masalah aljabar yang sederhana, dan mampu berpikir logis serta bernalar secara matematika dalam menyelesaikan suatu masalah. Sehingga, mata kuliah struktur aljabar sangat penting dikuasai mahasiswa dalam rangka meningkatkan daya nalar yang deduktif, logis dan sistematis.

Mempelajari Teori Grup membutuhkan kemampuan pemecahan masalah pembuktian matematis yang baik. Permasalahannya, kemampuan membuktikan mahasiswa khususnya pada topik teori grup masih sangat rendah. Hal ini didukung oleh pendapat (Ozdemir dan Ovez 2012) bahwa dalam melakukan pembuktian matematis formal, masih banyak kesulitan serius yang dihadapi oleh mahasiswa calon guru matematika dasar. Padahal, pembuktian merupakan hal yang sangat mendasar dalam matematika. Menurut (Stefanowicz 2014), bukti adalah esensi dari pembelajaran matematika. (Lesseig, dkk 2019) juga mengemukakan bahwa 
dosen di universitas akan sangat teliti dengan penjelasan mereka dan akan memberikan notasi-notasi dengan jelas dan setiap teorema akan dibuktikan. Lebih lanjut (Ozdemir dan Ovez 2012) memberikan pendapat bahwa bukti matematis menjadi penjamin pengetahuan matematika sehingga merupakan sebuah aktivitas penting dalam memahami matematika. Pembuktian matematis mengambil peranan penting dalam berbagai mata kuliah yang ada di Jurusan Matematika. (Hanna dan Hoyles 2010) juga mengemukakan bahwa bukti berfungsi sebagai penentu kebenaran klaim matematika, sebuah proposisi matematika dapat dikatakan benar setelah dibuktikan benar.

Terdapat beberapa faktor yang tentunya mempengaruhi kemampuan pemecahan masalah pembuktian matematis mahasiswa, salah satunya terkait dengan tekad dan daya juang mahasiswa dalam memecahkan masalah tersebut. (Hasan, 2016) berpendapat bahwa dalam menyelesaikan masalah pembuktian matematis dibutuhkan suatu kemampuan tingkat tinggi yang tentunya memerlukan usaha keras di dalamnya. Salah satu faktor yang bisa dikaitkan usaha keras tersebut adalah adversity quotient. (Stoltz 2004) mengemukakan bahwa $A Q$ (adversity quotient) merupakan suatu kecerdasan atau kemampuan dalam merubah, mengolah sebuah permasalahan atau kesulitan, dan menjadikanya sebuah tantangan yang harus diselesaikan supaya tidak menghalangi cita-cita dan prestasi yang akan diraih. Lebih lanjut Stoltz membagi 3 kategori adversity quotient yakni 1) climbers atau pendaki, yaitu orangorang yang seumur hidup membaktikan dirinya pada pendakian, maksudnya orang yang tidak menghiraukan latar belakang, keuntungan atau kerugian, nasib buruk atau nasib baik, si pendaki terus mendaki, 2) campers atau orang-orang yang berkemah, maksudnya orang yang pergi tidak seberapa jauh karena bosan, mengakhiri pendakian dan mencari tempat yang nyaman sebagai tempat bersembunyi dari situasi yang tidak bersahabat serta memilih untuk menghabiskan sisa-sisa hidup dengan duduk di tempat tersebut. Campers sekurang-kurangnya telah menanggapi tantangan pendakian, telah mencapai tingkat tertentu, dan telah mengorbankan banyak hal untuk sampai ketempat pemberhentian, dan 3) quitters atau yang berhenti, yaitu orang-orang yang berhenti, maksudnya orang yang menghentikan pendakian, menolak kesempatan yang diberikan oleh gunung, mengabaikan, menutupi, atau meninggalkan dorongan inti yang manusiawi untuk mendaki, serta meninggalkan banyak hal yang ditawarkan oleh kehidupan.

Beberapa studi lain terkait adversity quotient sejauh ini telah dilakukan oleh beberapa peneliti. (Hastuti, dkk 2017) mengemukakan bahwa adversity quotient merupakan kemampuan seseorang bertahan menghadapi kesulitan serta upaya apa yang perlu dilakukan untuk menyelesaikan masalah tersebut. Jika dikaitkan dengan pemecahan masalah, maka menurut (Sari, dkk 2016), dalam menyelesaikan masalah yang rumit, quitters cenderung menghindar dan tidak mau mencoba karena merasa tidak akan mampu menyelesaikannya, campers cenderung mencoba mengerjakannya tetapi ketika tampak rumit maka dia meninggalkannya, sedangkan climbers akan berusaha dengan keras untuk bisa menyelesaikan masalah tersebut.

Besarnya peranan pembuktian matematis dalam pembelajaran matematika menjadikan penelitian terkait faktor yang mempengaruhi kemampuan pemecahan masalah pembuktian matematis, dalam hal ini faktor yang akan diteliti adalah adversity quotient, khususnya dalam topik Teori Grup, menjadi penting untuk dilaksanakan. Hipotesis penelitian yang akan diuji dalam penelitian ini yakni terdapat pengaruh adversity quotient terhadap kemampuan pemecahan masalah pembuktian matematis topik Teori Grup. Lebih lanjut jenis dan kategori 
pengaruh adversity quotient terhadap kemampuan pemecahan masalah pembuktian matematis topik Teori Grup akan dipaparkan.

\section{Metode}

Penelitian ini menggunakan pendekatan kuantitatif dan merupakan penelitian korelasional untuk mengetahui pengaruh adversity quotient terhadap kemampuan pemecahan masalah pembuktian matematis topik Teori Grup. Populasi dalam penelitian ini adalah seluruh mahasiswa Program Studi Pendidikan Matematika Universitas Sulawesi Barat yang mengikuti mata kuliah Struktur Aljabar pada tahun akademik 2019/2020 dengan jumlah 71 mahasiswa. Populasi ini dipilih sebab topik Teori Grup terdapat pada mata kuliah Struktur Aljabar yang diprogramkan mahasiswa pada semester genap. Selanjutnya dipilih secara acak sebanyak 30 mahasiswa sebagai sampel dalam penelitian ini.

Untuk memperoleh data skor adversity quotient, digunakan Adversity Response Profile (ARP) Quick Take ${ }^{\mathrm{TM}}$. Instrumen ini merupakan instrumen baku yang dikembangkan oleh Stoltz (2004). Instrumen ini telah diuji coba oleh lebih dari 7.500 orang dari seluruh dunia dengan berbagai macam karier, usia, ras, dan kebudayaan. Dari hasil analisis formal terhadap hasilnya mengungkapkan bahwa instrumen ini merupakan tolok ukur yang valid untuk digunakan mengukur bagaimana orang merespons kesulitan dan merupakan peramal kesuksesan yang ampuh. Dari berbagai tes ulangan dan lanjutan juga diperoleh bahwa instrumen ini sangat konsisten. Instrumen ini terdiri dari 60 pernyataan dan terdiri dari empat indikator, control (kendali), origin and ownership (asal usul dan pengakuan), reach (jangkauan), dan endurance (daya tahan). Sedangkan untuk memperoleh data skor kemampuan pemecahan masalah pembuktian matematis topik Teori Grup digunakan Tes Kemampuan Pemecahan Masalah Pembuktian Matematis Topik Teori Grup yang terdiri dari 2 soal pembuktian mencakup materi sifat-sifat dasar grup dan grup siklik.

Data yang diperoleh dianalisis dengan analisis regresi linear sederhana menggunakan bantuan perangkat lunak. Sebelum dilakukan uji regresi linear sederhana untuk melihat pengaruh adversity quotient terhadap kemampuan pemecahan masalah pembuktian matematis topik Teori Grup, terlebih dahulu dilakukan uji prasyarat yakni uji normalitas dan uji linearitas. Pengujian yang digunakan adalah uji dua pihak dengan taraf signifikansi 5\%. Selanjutnya digunakan analisis lebih lanjut, yakni analisis korelasi $(R)$ untuk mengetahui jenis dan kategori pengaruh antara variabel bebas terhadap variabel terikat, dan analisis determinasi $\left(R^{2}\right)$ untuk mengetahui persentase sumbangsih pengaruh variabel bebas terhadap variabel terikat.

\section{Hasil}

Statistik skor adversity quotient yang diperoleh melalui instrumen Adversity Response Profile (ARP) Quick Take ${ }^{\mathrm{TM}}$, adversity quotient mahasiswa disajikan pada Tabel 1. 
Tabel 1. Statistik Skor Adversity Quotient

\begin{tabular}{llcc}
\hline & & Statistic & Std. Error \\
\hline & Mean & 128.53 & 2.121 \\
& 95\% Confidence Interval for Mean & Lower Bound & 124.20 \\
& Upper Bound & 132.87 \\
5\% Trimmed Mean & 128.09 \\
Skor_ARP & Median & 127.50 \\
& Variance & 134.947 \\
& Std. Deviation & 11.617 \\
& Minimum & 108 \\
& Maximum & 159 \\
& Range & 51 \\
\hline
\end{tabular}

Rata-rata skor ARP yang diperoleh adalah 128,53 dengan standar deviasi 11,617. Hal ini menunjukkan bahwa rata-rata skor adversity quotient mahasiswa berada pada kategori sedang (merupakan campers). Lebih lanjut skor adversity quotient mahasiswa dikategorikan pada Tabel 2 berikut.

Tabel 2. Kategori Adversity Quotient Mahasiswa

\begin{tabular}{cccc}
\hline Skor AQ & Kategori & Banyak Mahasiswa & Persentase \\
\hline$>134$ & Climber & 10 & $33 \%$ \\
$60-134$ & Camper & 20 & $67 \%$ \\
$<60$ & Quitter & 0 & $0 \%$ \\
& Total & & $100 \%$ \\
\hline
\end{tabular}

Adapun statistik skor kemampuan pemecahan masalah pembuktian matematis topik Teori Grup yang diperoleh melalui instrumen tes pembuktian disajikan pada Tabel 3.

Tabel 3. Statistik Skor Kemampuan Pemecahan Masalah Pembuktian Matematis

\begin{tabular}{llcc}
\hline & & Statistic & Std. Error \\
\hline Mean & 64.90 & 1.738 \\
95\% Confidence Interval for Mean & Lower Bound & 61.34 & \\
& Upper Bound & 68.46 & \\
5\% Trimmed Mean & 65.04 & \\
Skor_PMPM & & 65.00 & \\
& Median & 90.645 & \\
& Std. Deviance & 9.521 & \\
\cline { 2 - 4 } & Minimum & 45 \\
& Maximum & 83 \\
& Range & 38 & \\
& Interquartile Range & 14 & \\
\hline
\end{tabular}

Rata-rata skor kemampuan pemecahan masalah pembuktian matematis yang diperoleh adalah 64,90 dengan standar deviasi 9,521. Hal ini menunjukkan bahwa rata-rata skor 
kemampuan pemecahan masalah pembuktian matematis mahasiswa berada pada kategori sedang. Lebih lanjut skor tersebut dikategorikan pada Tabel 4 berikut.

Tabel 4. Kategori Kemampuan Pemecahan Masalah Pembuktian Matematis Mahasiswa

\begin{tabular}{cccc}
\hline Skor & Kategori & Banyak Mahasiswa & Persentase \\
\hline$\geq 80$ & Tinggi & 1 & $3 \%$ \\
$60-80$ & Sedang & 21 & $70 \%$ \\
$<60$ & Rendah & 8 & $27 \%$ \\
& Total & & $100 \%$ \\
\hline
\end{tabular}

Hasil uji prasyarat berupa uji normalitas menghasilkan data yang dirangkum pada Tabel 5 berikut.

Tabel 5. Rangkuman Uji Normalitas

\begin{tabular}{lccc}
\hline & & Shapiro-Wilk & \\
& Statistic & df & Sig. \\
\hline Skor_ARP & .977 & 30 & .745 \\
Skor_PMPM & .963 & 30 & .379 \\
\hline
\end{tabular}

Dari Tabel 1 diperoleh signifikansi untuk skor $A R P$ adalah 0,745 dan signifikansi untuk skor $P M P M$ adalah 0,379. Karena signifikansi variabel adversity quotient dan variabel kemampuan pemecahan masalah pembuktian matematis $>0,05$, maka dapat disimpulkan bahwa kedua data berasal dari populasi yang berdistribusi normal untuk taraf signifikansi 5\%. Adapun untuk hasil uji prasyarat yang kedua, yaitu uji linearitas, hasilnya dirangkum pada Tabel 6 berikut.

Tabel 6. Rangkuman Uji Linearitas

\begin{tabular}{|c|c|c|c|c|c|c|c|}
\hline & & & $\begin{array}{c}\text { Sum of } \\
\text { Squares }\end{array}$ & df & $\begin{array}{c}\text { Mean } \\
\text { Square }\end{array}$ & $\mathbf{F}$ & Sig. \\
\hline Skor & Between & (Combined & 2075.70 & 2 & 90.248 & .979 & .564 \\
\hline PMPM * & Groups & ) & 0 & 3 & & & \\
\hline \multirow[t]{7}{*}{ Skor_ARP } & & Linearity & 388.854 & 1 & 388.854 & 4.219 & .086 \\
\hline & & Deviation & 1686.84 & 2 & 76.675 & .832 & .658 \\
\hline & & from & 6 & 2 & & & \\
\hline & & Linearity & & & & & \\
\hline & \multicolumn{2}{|c|}{ Within Groups } & 553.000 & 6 & 92.167 & & \\
\hline & \multirow{2}{*}{\multicolumn{2}{|c|}{ Total }} & 2628.70 & 2 & & & \\
\hline & & & 0 & 9 & & & \\
\hline
\end{tabular}

Dari Tabel 6 diperoleh nilai Deviation from Linearity adalah 0,658. Karena nilai tersebut $>0,05$ maka dapat disimpulkan bahwa ada hubungan yang linear secara signifikan antara variabel adversity quotient dengan kemampuan pemecahan masalah pembuktian matematis pada taraf signifikansi $5 \%$.

Karena kedua uji prasyarat telah terpenuhi, maka pengujian dapat dilanjutkan pada uji regresi linear sederhana. Persamaan regresi linear sederhana yang diperoleh adalah: 


$$
Y^{\prime}=24,384+0,315 X
$$

Keterangan:

$\mathrm{Y}^{\prime}=$ Variabel Kemampuan Pemecahan Masalah Pembuktian Matematis Topik Teori Grup

$\mathrm{X}=$ Variabel Adversity Quotient

Hasil tersebut diperoleh dari Tabel 7 berikut.

Tabel 7. Rangkuman Coefficients

\begin{tabular}{ccccccc}
\hline Model & & \multicolumn{2}{c}{$\begin{array}{c}\text { Unstandardized } \\
\text { Coefficients }\end{array}$} & $\begin{array}{c}\text { Standardized } \\
\text { Coefficients } \\
\text { Beta }\end{array}$ & t & Sig. \\
& B & Std. Error & B & & \\
\hline \multirow{2}{*}{1} & (Constant) & 24.384 & 18.449 & & 1.322 & .197 \\
& Skor_ARP & .315 & .143 & .385 & 2.205 & .036 \\
\hline
\end{tabular}

Hasil uji koefisien regresi linear sederhana untuk melihat pengaruh variabel bebas (adversity quotient) terhadap variabel terikat (kemampuan pemecahan masalah pembuktian matematis topik Teori Grup) dirangkum pada Tabel 8 berikut.

Tabel 8. Rangkuman Uji Regresi Linear Sederhana

\begin{tabular}{llccccc}
\hline \multirow{2}{*}{ Model } & $\begin{array}{c}\text { Sum of } \\
\text { Squares }\end{array}$ & df & Mean Square & F & Sig. \\
\hline \multirow{2}{*}{1} & Regression & 388.854 & 1 & 388.854 & 4.861 & $.036^{\mathrm{b}}$ \\
\cline { 3 - 5 } & Residual & 2239.846 & 28 & 79.994 & & \\
& Total & 2628.700 & 29 & & & \\
\hline
\end{tabular}

Pada Tabel 8, terlihat bahwa nilai signifikansi regression adalah 0,036. Karena signifikansi < 0,05, maka dapat disimpulkan bahwa pada taraf signifikansi $5 \%$, terdapat pengaruh signifikan adversity quotient terhadap kemampuan pemecahan masalah pembuktian matematis topik Teori Grup. Lebih lanjut jenis pengaruh dan kategori pengaruh dipaparkan melalui data pada Tabel 5 berikut.

Tabel 9. Rangkuman Analisis Korelasi dan Analisis Determinasi

\begin{tabular}{ccccc}
\hline Model & R & R Square & Adjusted R Square & $\begin{array}{c}\text { Std. Error of the } \\
\text { Estimate }\end{array}$ \\
\hline 1 & $.385^{\mathrm{a}}$ & .148 & .117 & 8.944 \\
\hline
\end{tabular}

Tabel 9 menunjukkan nilai $\mathrm{R}$ sebesar 0,385. Hal ini menunjukkan bahwa pengaruh adversity quotient terhadap kemampuan pemecahan masalah pembuktian matematis topik Teori Grup merupakan pengaruh positif dan berada pada kategori 
sedang. Adapun nilai $R$ square yang diperoleh adalah sebesar 0,148. Ini menunjukkan bahwa persentase sumbangsih pengaruh variabel adversity quotient terhadap kemampuan pemecahan masalah pembuktian matematis topik Teori Grup sebesar $14,8 \%$ dan $85,2 \%$ sisanya dipengaruhi oleh faktor-faktor lain.

Berdasarkan hasil yang diperoleh pada uji regresi linear sederhana, terdapat pengaruh adversity quotient terhadap kemampuan pemecahan masalah pembuktian matematis topik Teori Grup. Selanjutnya, koefisien variabel adversity quotient pada persamaan regresi linear sederhana bernilai positif sehingga dapat disimpulkan bahwa adversity quotient berpengaruh positif terhadap kemampuan pemecahan masalah pembuktian matematis topik Teori Grup. Juga dapat disimpulkan bahwa adversity quotient berpengaruh positif terhadap kemampuan pemecahan masalah pembuktian matematis topik Teori Grup namun pengaruhnya berada pada kategori lemah.

\section{Pembahasan}

Menurut (Sari, dkk 2016), kategori adversity quotient seseorang akan mempengaruhi respons mereka terhadap masalah yang dihadapi. Dalam penelitian (Adisti 2015), ditemukan hasil bahwa pembelajar kategori quitters melakukan proses pemecahan masalah matematis yang sangat kurang dibandingkan dengan pembelajar yang berada pada kategori campers dan climbers. Begitupun dengan hasil penelitian (Sahyar dan Rika 2017) yang menyimpulkan bahwa adversity quotient pembelajar memiliki hubungan dengan kemampuan pemecahan masalah mereka. (Mardika dan Insani 2017) juga memperoleh hasil pada penelitiannya bahwa terdapat relasi antara adversity quotient dan kemampuan pemecahan masalah matematika, adversity quotient dapat memperngaruhi cara berpikir pembelajar dalam menyelesaikan masalah pembuktian matematis.

Beberapa hasil penelitian di atas menunjukkan bahwa adversity quotient berpengaruh positif terhadap kemampuan pemecahan masalah matematika pembelajar. Meskipun beberapa penelitian tersebut dilakukan pada tingkat sekolah menengah, bukan pada tingkat perguruan tinggi, namun teori-teori yang diperoleh dan dipaparkan menunjukkan adanya korelasi antara kedua variabel tersebut. Hasil penelitian ini menunjukkan bahwa adversity quotient mahasiswa juga mempengaruhi kemampuan pemecahan masalah matematis mereka, khususnya masalah pembuktian pada topik Teori Grup.

Temuan samping penelitian ini adalah masih rendahnya kemampuan pemecahan masalah matematis mahasiswa pada topik Teori Grup. Hal ini sebaiknya ditindaklanjuti dengan berbagai upaya oleh dosen terkait. Upaya-upaya yang dilakukan dapat terkait model pembelajaran yang digunakan, referensi yang memadai dan mutakhir, atau perangkat pembelajaran yang sesuai dengan materi-materi pembuktian.

\section{Kesimpulan}

Dari pembahasan pada bagian sebelumnya, dapat disimpulkan bahwa adversity quotient berpengaruh terhadap kemampuan pemecahan masalah pembuktian matematis topik Teori 
Grup. Lebih lanjut ditemukan bahwa pengaruh adversity quotient terhadap kemampuan pemecahan masalah pembuktian matematis topik Teori Grup merupakan pengaruh positif namun berada pada kategori lemah.

\section{Ucapan Terima Kasih}

Terima kasih kepada Program Studi Pendidikan Matematika Universitas Sulawesi Barat yang memberi dukungan terbesar dalam pengumpulan data pada penelitian ini, khususnya untuk mahasiswa Program Studi Pendidikan Matematika angkatan 2018.

\section{Referensi}

Adisti, E. (2015). Profil siswa dalam memecahkan masalah perbandingan berdasarkan langkah-langkah Polya diitnjau dari adversity quotient. Tesis. (Tesis magister tidak dipublikasikan). Universitas Negeri Malang, Malang.

Hanna, G., \& Barbeau, E. (2010). Proofs as bearers of mathematical knowledge in explanation and proof in mathematics: philosophical and educational perspectives. 85 $-99$.

Hasan, B. (2016). Proses berpikir mahasiswa dalam mengkonstruksi bukti menggunakan induksi matematika berdasarkan teori pemrosesan informasi. APOTEMA: Jurnal Pendidikan Matematika. 33 - 40.

Hastuti, T. D., Sari, D. R., \& Riyad. (2017). Student profile with high adversity quotient in math learning. IOP Conf. Series: Journal of Physics: Conf. Series 983 (2018) 012131.

Lesseig, K., Hine, G., Gwi Soo Na, \& Boardman, K. (2019). Perceptions on proof and teaching of proof: a compariosn across preservice secondary teachers in Australia, USA, and Korea. Mathematics Education Research Journal, 31, 393 - 418.

Mardika, F., \& Insani, S. U. (2017). Adversity quotient and students' problem solving skill in mathematics. $4^{\text {th }}$ ICRIEMS Proceedings. Yogyakarta.

Ozdemir, E., \& Ovez, F. T. D. (2012). A research on proof perceptions and attitudes towards proof and proofing: some implications for elementary mathematics prospective teachers. Procedia Social and Behavioral Sciences. 2121 - 2125.

Sahyar \& Fitri, R.K. (2017). The effect of problem-based learning model (PBL) and adversity quotient (AQ) on problem-solving ability. American Journal of Educational Research, 5(2), 179-183.

Sari, K.C., Sutopo, \& Aryuna, D.R. (2016). The profile of students; thinking in solving mathematics problems based on adversity quotient. Journal of Research and Advances in Mathematics Education, 1, 36-48. 
Soenarto, M., 2011, Pemanfaatan peta konsep dalam menyelesaikan soal pembuktian pada Teori Grup, Seminar Bulanan Prodi Matematika FKIP UHAMKA, Jakarta: FKIP UHAMKA.

Stefanowicz, A. (2014). Proof and mathematical reasoning. Birmingham: University of Birmingham Mathematics Support Centre.

Stoltz, P. G. (2004). Adversity quotient: mengubah hambatan menjadi peluang (Terjemahan oleh Hermaya, T). Jakarta, Indonesia: Penerbit PT Grasindo. 